\title{
AZ ÜZLETI KAPCSOLATOK ÉRTÉKTEREMTŐ SZEREPÉNEK VIZSGÁLATA STRATÉGIAI NÉZÖPONTBÓL
}

Az üzleti kapcsolatok szerepének vizsgálata interdiszciplináris megközelítést igényel. Ez a tanulmány a stratégiai menedzsment szemszögéből foglalja össze azokat a témaköröket, melyek az üzleti kapcsolatok vizsgálatához kapcsolódnak. Az üzleti kapcsolatok felértékelődésének tényezőit követően meghatározza a stratégiai szempontból releváns üzleti kapcsolatokat, röviden bemutatja a kutatás hátterét képező elméleti megközelítéseket, majd ezekre építve az üzleti kapcsolatok vizsgálatának lehetséges szintjeit. ${ }^{1}$

Az üzleti kapcsolatok és azok rendszerét vizsgáló nézőpont mögött az eredetileg a termelési stratégia kialakításához kapcsolódó venni vagy gyártani kérdés felértékelődése húzódik meg. Ez a kérdés a szervezetközi kapcsolatok szerepének előtérbe kerülésével a venni, gyártani vagy kooperálni kérdéssé alakult át, és a vállalati stratégia kialakítása során fontos döntési kritériumként jelenik meg. A vállalatok stratégai céljaik megvalósításakor nemcsak saját tevékenységükre tekintenek, hanem a környezeti komplexitás által támasztott követelményeknek megfelelően egy tágabb kontextusba helyezik azokat a tevékenységeket, melyeket saját maguk kívánnak elvégezni, másoktól megvásárolni vagy más szereplőkkel együttműködve végrehajtani. Ezt a kiterjesztett szemléletmódot az ellátási lánc ${ }^{2}$ jelenti, ami különböző vállalati tevékenységek, értékláncok összekapcsolódásával nyújt értéket a végső fogyasztó számára. Mivel a vállalati értéklánc a szállítói és vevői oldalon kapcsolódik az ellátási lánchoz, a másik a kapcsolóđó szemléletmód a kapcsolatmarketing ${ }^{3}$. Ez a tanulmány alapvetően stratégiai menedzsment nézőpontból tekint az üzleti kapcsolatokra, azonos szemléletmódot tükröz, mint az említett két, a kutatásunk során szintén alkalmazott koncepció. Mindhárom nézet hátterében az az alapkérdés húzódik meg, hogy hogyan tudjuk lebontani a szervezeti határokat és felváltani őket különböző üzleti kapcsolatokkal a vállalati stratégia sikeres megvalósítása érdekében.

A kutatás gyakorlati relevanciáját az adja, hogy Magyarországon is jórészt befejeződött az a folyamat, ami az Egyesült Államokban és a fejlett világ más részein már a nyolcvanas években megkezdődött, vagyis a nagyvállalati forma felbomlása, amit új alapokon szerveződő üzleti kapcsolatok hálózata alkot. Különböző iparágakban a vállalati hierarchiát önálló üzleti egységek együttesei váltották fel. Ezt a sokkal inkább piac irányította képződményt közkeletűen üzleti kapcsolatok hálózatának nevezik, ami mind az elméletalkotó, mind a gyakorlati szakemberek számára fontos gazdálkodástani kérdéseket vet fel, így vizsgálata célszerű. A magyar gazdaság számára a vállalatközi kapcsolatok alakulása szintén rendkívüli jelentőséggel bír, hiszen a piacgazdaság immár több mint egy évtizedes működése során kialakult vállalati kapcsolatrendszerek meghatározzák a magyar gazdaság fejlődését, a reálszféra versenyképességére gyakorolt hatását tekintve fontos tényezői az Európai Uniós csatlakozás sikerének is. Bármely ország gazdaságát jellemzik a vállalatközi kapcsolatrendszerek formái, illetve, hogy ezek a kapcsolatrendszerek mennyiben összeegyeztethetők a nemzetközi tendenciákkal. Egyre fontosabbá válik tehát, hogy a vállalatok ismerjék, és értékelni tudják az egyes létező, vagy potenciális üzleti 
kapcsolataikat, s e tudás alapján képesek legyenek azok megfelelő működtetésére a vállalat értékének növelése érdekében.

\section{Az üzleti kapcsolatok felértékelődésének tényezői}

Napjainkban megfigyelhető tendencia, hogy az egyre rövidebb időközönként megjelenő új technikai lehetőségek hatására a termékéletgörbék rövidebbek, az új termékek, szolgáltatások megjelenése gyakoribb. $\mathrm{Az}$ innovációs periódus megröviditése egyre inkább túlfeszíti az egyedi szervezet hatáskörét, és ily módon a stratégiai együttműködéseket támogatja, amelyekben a cégek felosztják az új termékek fejlesztési szakaszának rövidüléséből fakadó terheket (Camagni, 1991).

További meghatározó tényező a globalizáció jelensége, ami egyrészt jelenti azt a lehetőséget, és egyben kényszert a vállalatok számára, hogy megkeressék a legmegfelelőbb helyet és módot az adott tevékenység elvégzésére. A multinacionális vállalatok külföldi működőtőke beruházásokon keresztül hozzák létre saját leányvállalati hálózatukat (Bayer - Czakó, 1999). A helyi vállalatok számára a világgazdaság vérkeringésébe való bekapcsolódási lehetőséget jelenti egyrészt a globális vállalatok beszállítói hálózatában való rẹ́szvétel, másrészt a helyi sajátosságoknak megfelelő, és a helyi piacot kiszolgáló vállalatok hálózatába való bekapcsolódás. Napjaink világgazdasági trendjeinek jellemzői között megfigyelhető tehát egyrészt a globalizáció, ami a multinacionális társaságok előrretörésével jellemezhető, és emellett egy lokalizációs folyamattal is, ami a kisebb földrajzi régiók, a helyi specialitások kifejlődésének kedvez.

A gazdasági környezet felgyorsult, sok esetben kiszámíthatatlan változásai megváltoztatták a verseny dimenzióit is. A vállalatok már nem csupán termékeikkel, szolgáltatásaikkal versenyeznek egymással, hanem a létrehozásukhoz szükséges képességek terén is. Ezek folyamatos megújítása egyre inkább úgy tűnik, hogy kollektív tevékenységek útján valósítható meg, ahol az egyes résztevékenységek változási rugalmassága igen nagy. A stratégiai együttműködések példátlanul gyors elterjedése, sok más dolog közt, a cégek kockázatcsökkentő kisérletének tulajdonítható.

Az üzleti kapcsolatok működtetésével jelentős költségmegtakarítások érhetők el. Ez már önmagában elegendő indokot jelent, hiszen a kilencvenes évek vál- lalati gazdálkodására leginkább a költségek csökkentése révén elért hatékonyságnövelés volt jellemző.

Mindezeket összefoglalóan tehát amennyiben a környezeti feltételekhez való egyik legmegfelelőbb alkalmazkodás módja a vállalatok közötti üzleti kapcsolatok révén valósítható meg, ez azt jelenti, hogy ennek legfőbb mozgatórugója a vállalatok hosszú távú nyereséges működésének biztosítása. A vállalatok tehát azért kooperálnak, alakítanak ki új üzleti kapcsolatokat, hogy csökkentsék költségeiket, növeljék tevékenységeik hatékonyságát, megosszák a kockázatot stb., és ezáltal hosszabb távon saját nyereségességük, s a vállalatuk értékének növeléséhez járuljanak hozzá. ${ }^{4}$

\section{A stratégiai szempontból releváns üzleti kapcsolatok}

A társadalmi munkamegosztásban különböző tevékenységek kapcsolódnak össze. Ezek között a tevékenységek között szervezeti határok húzódnak meg, melyek lehetnek vállalaton belüliek, illetve vállalaton kívüliek is. A belső és külső határvonalak kettős megkülönböztetése a stratégia szempontjából az azonos vagy eltérő tulajdonoson alapul. Ezt azért fontos kiemelni, mert a vállalati stratégát a tulajdonos határozza meg (Rappaport, 2002), így az üzleti kapcsolatok a partnerek összeegyeztethető stratégiájára épülnek. Belső határokról van szó tehát különböző jogi személyiségű vállalatok esetében is, ha tulajdonosuk azonos. A külső vállalati határ elsődleges meghatározója pedig a különböző tulajdonos és az általa meghatározott stratégiai irány. A stratégiai menedzsment szempontjából azok az üzleti kapcsolatok fontosak, melyek leginkább befolyásolják a vállalati stratégia megvalósítását. Másképpen fogalmazva leginkább hozzájárulnak a vállalati értékteremtéshez. Stratégiai nézőpontból elsősorban tehát a tulajdonosi érték növekedésére gondolunk, kiemelve, hogy ez szorosan öszszekapcsolódik a vevői érték növekedésével. Ahogy a vállalat alapvető célját tekintve a nyereségszerzés, mint cél elválaszthatatlan a fogyasztói igény kielégítésétől, a tulajdonosi érték tartós növekedése sem valósítható meg a vevői érték gyarapodása nélkül.

A kutatás egyik legfontosabb kérdését képezi, hogy hogyan tudjuk meghatározni és megfelelő módon működtetni a vállalat számára azokat az üzleti kapcsolatokat, melyek az értékteremtésben a legnagyobb szerepet játsszák. 


\section{A kutatás számára meghatározó elméleti keret}

A stratégiakutatás számos kutatási területhez, más tudományterület által vizsgált jelenséghez kapcsolódik, és korántsem egységes elméleti iskolát takar. Mintzberg (1990) a stratégiai menedzsment területén kialakult gondolati iskolákat kilenc kategóriába sorol$\mathrm{ta}^{5}$. Gondolati iskola alatt a stratégiai menedzsment témakörében kikristályosodott gondolatok skáláját érti, amely a kutatók egy konkrét csoportjához kapcsolódik. Ennek a megközelítésnek az az előnye, hogy mindegyik iskola hozzáadott értékét és konkrét hiányosságait elég jól fel lehet térképezni. Mintzberg ugyanakkor kimutatta, hogy mindegyik iskola a teljes kép valamelyik aspektusával foglalkozik, és figyelmen kívül hagyja a többi nézőpontot. E tanulmánynak nem célja minden stratégiai menedzsmentiskola bemutatása. Azon elméleti irányok ismertetésére szorítkozik, melyek véleményünk szerint jól alkalmazhatók az üzleti kapcsolatok kutatása elméleti keretének kialakításához. Ehhez Elfring és Volberda (1996) szintetizálási kísérletéhez hasonlóan a kutatásunk számára legfontosabbnak tartott elméleti megközelítéseket vesszük sorra ${ }^{5}$. Ezzel elfogadva Bowman (1990) azon meglátását, hogy a stratégiamenedzsment területén belül szélsőségesen szétválnak egyrészt az analitikus megközelitések, amelyek nagyon szorosan kapcsolódnak a konkrét alapdiszciplínához, másrészt pedig a klinikai megközelitések, amelyek elsősorban a stratégiai menedzsmenten belüli fogalmak és technikák kidolgozásával foglalkoznak. Whitley (1984) terminológiáját követve elmondhatjuk, hogy az analitikus megközelítés esetén a stratégiai kutató egy alapdiszciplínát választ csoportként, míg a klinikai megközelítésnél a kutató elsősorban a menedzsmentre vagy a vezetésre koncentrál, mint fó csoportra. Az analitikus megközelítés egy elméletorientált, tudományos megközelítés, amely szisztematikus megfigyelésekre és mérésekre alapul. Minden kutató, aki a stratégiai menedzsmentnek valamelyik analitikus iskolájába tartozik, ugyanazt a szigorú módszertani alapelvet használja. A klinikai megközelítés viszont problémaorientáltabb. Ebben az induktív megközelítésben fontos a kutató szubjektív ítélete, értékelése, a kísérletező módszer. Az eredmény pedig egy leíró tudás, amely alapfogalmak, eszközök, csináld vagy ne csináld útmutatásokként jelenik meg. A klinikai megközelítés nem épül egy konkrét elméletre, inkább multidiszciplináris megközelítést alkalmaznak, amelyben a legfontosabb értékelési kritérium az, hogy a megoldás megfelelő legyen. Kutatásunkban tehát a klinikai megközelítést alkalmazzuk, melyhez a következő elméletekre támaszkodunk.

A társadalmi struktúra elmélete a strukturális tényezők szerepét hangsúlyozza a kapcsolatok elősegítésében. Az elmélet arra tesz kísérletet, hogy az együttműködések megjelenését a vállalatokat körülvevő teljes rendszer feltételeiből vezesse le. A struktúrák személyek, csoportok, szervezetek és ezek kapcsolatainak társadalmi pozícióiból épülnek fel, melyek egyszerre különbözőek és egymáshoz kapcsolódók. A társadalmi struktúraelmélet a kapcsolaton kívüli dimenziókra tekint az együttműködés és a koordináció előrejelzéséhez.

Fontosnak tartjuk továbbá a kapcsolódó beágyazottsági szemléletet (Granovetter, 1985), amelyben a társadalmi kontextus fogalma nem egyszer s mindenkorra szóló befolyás, hanem egy állandó, az interakciók során mindvégig épuilő és újraépülő folyamat. A gazdasági szereplők nem viselkednek a társadalmi kontextuson kívüli atomizált egyedekként, és nem követnek kitartóan szolgai módon változtathatatlan szokásokat vagy normákat. Következésképp, az opportunizmus nem kezelhető a gazdasági viselkedés külső meghatározó elemeként. Erre az elméletre épül a kutatás során az üzleti kapcsolatok kontextuális tényezőinek vizsgálata.

A tranzakciós költségelmélet és a stratégiaelmélet kapcsolódásának egyik kiemelt területeként kezelhető annak a kérdésnek a megválaszolása, hogy a cég előállítson vagy megvásároljon egy bizonyos árucikket vagy szolgáltatást. Ez a tranzakciós költségelmélet szerinti megfogalmazásban a piac vagy a hierarchia közötti választást jelent. Az előállítás kontra megvásárlás kérdésével foglalkozó korábbi kutatásokat jelentősen befolyásolta a tranzakciós költségelmélettel foglalkozó közgazdászok nézete, akik azt hangsúlyozták, hogy bármilyen tranzakciónak milyen velejáró szerződéskötési veszélyei vannak (Williamson, 1975). Kutatásunk során az üzleti kapcsolatokra vonatkozóan azt mondhatjuk, hogy piac és hierarchiától különböző együttműködési forma kialakításának köztes helyzetekben van értelme, amikor a tranzakciós költségek nem olyan magasak, hogy hierarchikus kontroll lenne szükséges, de nem is olyan alacsonyak, hogy lehetővé tennék a piaci alapú csere tranzakciót. 
A hálózati szemlélet arra hívja fel a figyelmet, hogy minden egyes tranzakció korábbi kapcsolatok sorába, illetve egy szélesebb kapcsolati hálóba illeszkedik. Emiatt alaposan át kell vizsgálni, kibővíteni a tranzakciós költségekkel és a szerződéskötéssel kapcsolatos értelmezéseket (Gulati, 1995). A tranzakciós költség megközelítés továbbá azt hangsúlyozza, hogy a tranzakciók költségének csökkentésével hatékonysági előnyhöz lehet jutni, de a hálózati perspektíva szerint figyelembe kell azt is venni, hogy milyen stratégiai előnyök származnak abból, hogy nemcsak egyetlen kapcsolatot optimalizál a cég, hanem az egész kapcsolati hálóját (Dyer - Singh, 1998). Ehhez igazodva kutatásunk célja nemcsak az egyes üzleti kapcsolatok jellemzőinek, és azok működtetési gyakorlatának önmagukban történő vizsgálata, hanem a vállalati kapcsolatportfólió értékelése is.

A vállalat és a környezet kapcsolatának leírásakor az erôforrás-alapú elmélet a külső erőforrásoktól való függést helyezi vizsgálatai középpontjába. A szervezetek túlélése az erőforrások megszerzésének és megtartásának képességén múlik (Pfeffer - Salancik, 1978). A stratégia- és vállalatelméleti szakemberek rámutattak arra, hogy egyetlen szervezet sem képes minden szükséges erőforrást saját maga előállítani, ezért más szervezetektől kell azokat beszerezniük. Erre alapozva megkülönböztethetünk a vállalatok szempontjából saját, birtokolt erőforrásokat és megszerezhető erőforrásokat. Az erőforrások egy része egyben a vállalatok központi kompetenciáit is jelenti - azaz olyan szakértelmet és különleges képességet, mely adott időben versenyelőnyt jelent a releváns piacokon (Prahalad - Hamel, 1990). A vállalatok üzleti kapcsolatai fontos szerepet játszanak a képességek átadásában és cseréjében, tehát nemcsak a piaccal és a hierarchiával szemben jelentenek alternatívát, hanem a készségek megszerzésének is egy lehetséges módját jelentik.

Ellentétben az előbbi elméletekkel, a tudásra alapozott elmélet nem jogi keretként, szerződéshalmazként vagy a hierarchikus koordináció megvalósulásaként kezeli a vállalatot, hanem egyfajta tudás, ismerethalmazként. A verseny hagyományos felfogása szerint a környezeti feltételek és az iparág alapvető jellemzői határozzák meg a vállalati stratégiát. A tudásalapú elmélet ennek nem mond ellent, csak kihangsúlyozza az állandóan váltózó környezeti tényezők közül a tudás felértékelődésének szerepét. Ily módon azzal, hogy úgy tekint a tudásra, mint a vállalat legfontosabb erőforrására, egyben az erőforrás-alapú elmélet egyik válfajának is tekinthető (Grant, 1996).
Hamel egy többed magával írt cikkében (Hamel et al., 1989) amellett érvelt, hogy a japán és amerikai cégek között kötött szövetségek közül sok úgy ért véget, hogy az amerikai cég jelentős versenyhátrányt szenvedett, mert a japán partnerek mindent eltanultak, amit lehetett, azután pedig felmondták a szövetséget, hogy önállóan aknázzák ki az újonnan eltanult tudásból eredő lehetőségeket. Azóta már elfogadott és több kutató által továbbfejlesztett gondolat az, hogy minden kétszereplős kapcsolatot tanulási versenyfutásként kell tekinteni, amelyben az egyik partner a gazdasági megtérülés nagyobb hányadára tesz szert, mivel jobb tanulási készségekkel vagy befogadó kapacitással rendelkezik. Kutatásunkban a vállalatok közötti partnerkapcsolatokon belüli tudástranszfert is vizsgáljuk annak figyelembevételével, hogy míg a tanulási versenyfutás irodalma általában a kétpólusú elemzési szintre összpontosít, fontos annak vizsgálata, hogy a versenyfutások dinamikáját befolyásolhatja az is, hogy az egyes partnerek a szövetségen kívül milyen tevékenységi portfólióval rendelkeznek, vagy milyen a relatív tevékenységi kiterjedtségük vagy tevékenységi körük. Például, ha az egyik partner csak egy üzleti kapcsolatrendszerhez kapcsolódik és nincs más üzleti szegmens, amelyben kiaknázhatja azt, amit a kapcsolatból tanul, akkor valószínű, hogy a szövetségben maradás közös hasznát nagyobbnak fogja értékelni, mint azt a hasznot, amit a gyors tanulás révén a szövetség felmondásával önállóan el tudna érni.

A megbizó-ügynök elmélet azokkal a problémákkal foglalkozik, amelyek akkor lépnek fel, amikor az egyik fél, a megbízó egy másik felet, ügynököt bíz meg valamely munka elvégzésével. Az ügynökség problémái az ilyen jellegü munkamegosztás során kialakuló információs aszimmetriából és a két fél ellenkező céljaiból és kockázatvállalási preferenciájából erednek (Fama - Jensen, 1983). Az ügynöki rendszer költségeinek két típusa van: (1) befektetések ellenőrzési rendszerekbe, amelyek célja a megbízó információhiányának csökkentése; és (2) teljesítményalapú ösztönzések által a kockázat ügynökre hárításának költsége. Az ügynökelmélet egy hatékonysági kritérium alapján megjósolja, hogy a megbízó és az ügynök közötti szerződés alapját melyik irányítási forma fogja képezni. Kutatásunk számára hasznos az ügynökelmélet az olyan szervezeti kapcsolatok megértéséhez, amelyekben az irányítást különböző célok és hiányos információ feltételei mellett kell gyakorolni. Az elmélet azért értékes, mert pontosan meghatározza, hogy 
a szerződő felek között hogyan oszlik meg a kockázat, hogyan váltják ki egymást az információ és a kockázatviselés költségei, és hogy melyek a szerződéses kapcsolatok ösztönzői, így felhasználható a piaci cserekapcsolatok és a szervezeti hierarchia között kialakuló egyéb kapcsolati formák vizsgálatára.

\section{Az üzleti kapcsolatok vizsgálatának szintjei}

A kutatás előkészítése során áttekintett szakirodalom alapján az üzleti kapcsolatokat három szinten kívánjuk vizsgálni. A három szint különbözőségét a vizsgálat tárgyának különbözősége adja. Ezek nem egymást kizáró, inkább részhalmaz jellegú kapcsolatban állnak egymással. A három elemzési szint a következő:

1. a kétoldalú üzleti kapcsolatok vizsgálata,

2. egy adott vállalat üzleti kapcsolatainak vizsgálata,

3. vállalatok egy adott csoportjának üzleti kapcsolatrendszere.

\section{A kétoldalú üzleti kapcsolatok vizsgálata}

A kétoldalú kapcsolatok vizsgálatához kiindulásként elsősorban Mohr és Spekman (1994) által felállított szociálpszichológiai ,, sikeres partnerkapcsolati modellt" használjuk. Modellükben két sikeres partnerkapcsolati indikátort használnak: egy objektív indiká-

1. ábra

A partnerkapcsolat sikeréhez társított tényezők

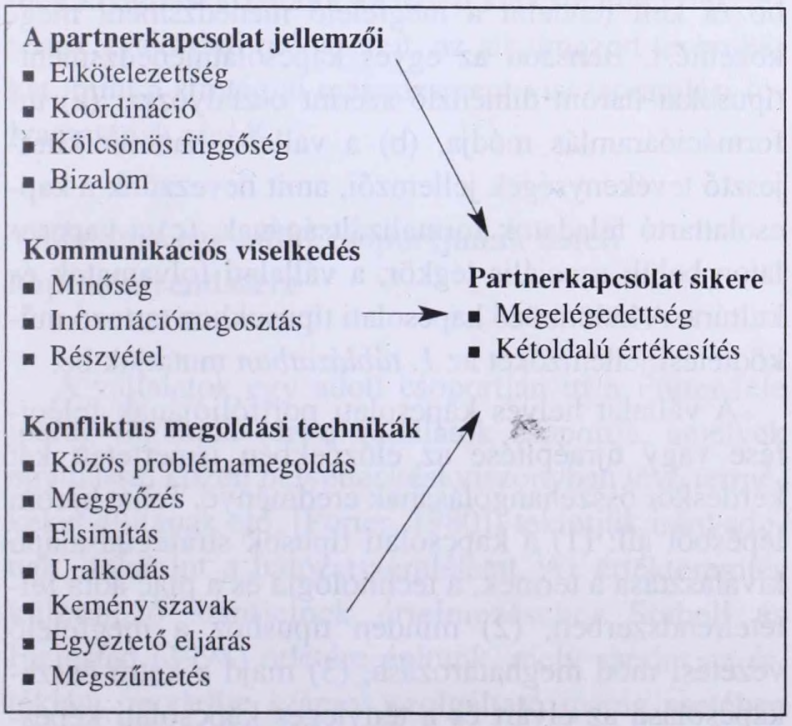

Forrás: Mohr, J. and Spekman, R. 1994: 137 . o. tort (eladási mennyiség áramlása a partnerek között) és egy érzelmi mértékegységet (elégedettség a másik féllel). A kapcsolat sikere attól függ, hogy a partnerkapcsolatnak hogyan sikerül megvalósítania a partnerek által felállított teljesítmény elvárásokat. Ezek az 1 . ábrában összefoglalt tényezőktől függnek.

Kiindulópontként általánosságban annyit mondhatunk a stratégiai üzleti kapcsolatokról, hogy „célirányos stratégiai kapcsolatokként határozhatók meg különálló cégek között, amelyek összeegyeztethető célokkal rendelkeznek, kölcsönös előnyökre törekednek és elismerik a magas szintű kölcsönös függőség tényét" (Mohr - Spekman, 1994: 135. o.). Közös erőfeszítéseket tesznek azon célok elérésére, amelyet egyedül múködve nem tudnának könnyen elérni. A stratégiai üzleti kapcsolatok tehát olyan jellegzetességeket mutatnak, amelyek megkülönböztetik őket a hagyományosabb üzleti kapcsolatoktól. Mohr és Spekman kutatásai kimutatták, hogy a sikeresebb partnerkapcsolatok ezeket a jellegzetességeket nagyobb intenzitással képviselik, mint a kevésbé sikeres kapcsolatok. Kiindulásként elfogadjuk tehát, hogy a stratégiai üzleti kapcsolat legfontosabb ismérve, hogy a felek saját stratégiájuk megvalósításában fontosnak tartják az adott kapcsolat sikerét, és céljuk, hogy azt a megvalósításban elfoglalt helyének megfelelően működtessék.

Miközben a partnerkapcsolatot gyakran csodaszernek tartják, receptnek a versenyelőny elnyerésére, figyelmen kívül hagyják azt a tényt, hogy nagyon sok stratégiai üzleti kapcsolat nem sikeres. Az üzleti kapcsolatok vizsgálata gyakran elfeledkezik annak hátrányairól, kockázatairól. Ilyen lehet például a komplexitás növekedése, a hatalomvesztés és az információs aszimmetria, amelyek velejárói lehetnek a kapcsolatoknak. Fontos tehát azon tényezők ismerete, amelyeket a partnerkapcsolat sikeréhez társítanak, de nem egyedüli meghatározó a partnerek kiválasztásában, mint ahogy a meglévő partnerkapcsolat múködtetésében sem. Kutatásunk során fontosnak tartjuk a sikertelen üzleti kapcsolatok vizsgálatát is, mivel az ezekből származó tapasztalatok alapján jelentősen bővíteni tudjuk a stratégiai üzleti kapcsolatokról szerzett tudásunkat.

Az egyedi vagy kétoldalú üzleti kapcsolatok vizsgálata során kutatásunk alapvető célja, hogy a meglévő modell kiegészítésével meghatározzuk azokat a tényezőket, melyek a stratégiai üzleti kapcsolatok sajátjai. Ez már átvezet a következő vizsgálati szintre, amikor egy adott vállalat üzleti kapcsolatait tekintjük a vizsgálat tárgyának. 


\section{Egy vállalat üzleti kapcsolatainak vizsgálata}

Ezen a vizsgálati szinten az adott vállalat kapcsolatrendszerét tekintjük át. A kapcsolatrendszer általános jellemzésén túlmenően célunk a vállalat stratégiai üzleti kapcsolatainak részletes elemzése. Előfeltételként azt mondhatjuk, hogy a hálózati kapcsolatok különbözőségét alapvetően a vállalat stratégiájának megvalósításához való hozzájárulás határozza meg. A stratégiai partnerkapcsolat tehát elég tág fogalomként értékelhető, mivel a piaci és hierarchia folyamatokban megvalósítható együttműködési formák közül bármelyik lehet stratégiai jelentőségű. Elméleti kiindulási alapot ezen a szinten az értéklánc és az ellátási lánc modell integrálása jelenti. Azt feltételezzük, hogy a vállalatok üzleti kapcsolatai közül azok fontosak a vállalati értéknövelés szempontjából, melyek a vállalati értéklánc elsődleges tevékenységeit kapcsolják össze az ellátási lánc többi szereplőjével. Kutatási célunk ennek igazolása vagy cáfolata.

A vállalati stratégiával összefüggésben e kapcsolatok portfóliójának kialakítása és működtetése a feladat. A vállalatok különböző termék- és szolgáltatás portfóliókkal rendelkeznek, így ehhez kapcsolódóan a vállalatoknak egyszerre több, különböző kapcsolati típus menedzselésére kell összpontosítaniuk. Stratégiai irányelvek adnak útmutatást a vállalatvezetőknek a kialakítandó kapcsolatokra, melyek vezetése ezután a vállalati teljesítmény fontos meghatározó eleme lehet. A kapcsolat stratégia megválasztása az általános vállalati stratégia függvénye, így környezetfüggő, fókuszpontokat tartalmaz a jövőre vonatkozóan. Jogosan feltételezhető, hogy kapcsolattípusonként eltérő, így ennek függvényében különböző működtetési és értékelési elvek alkalmazását igényli.

Kutatásunkban a különböző vállalatközi kapcsolatok kialakításánál és menedzselésénél érdekes, hogy milyen vezetési struktúrát, illetve kapcsolati formát válasszon egy cég különböző környezeti körülmények között. Ez egy stratégiai döntés, mivel kölcsönhatásban van azzal, hogy a cég hogyan határozza meg saját vállalati határait és alapvető képességeit. Az ehhez kapcsolódó szervezeti kérdés - ami már a stratégia megvalósítását jelenti - az, hogy mi a különböző típusú kapcsolatok megfelelő menedzselésének módja. Ehhez egy kutatásokon alapuló tipizálásra építünk, ami Bensaou $(1997 ; 1999)$ nevéhez kapcsolódik és a „vevôi-szállitói kapcsolatok portfóliói" címet viselő tipizálás. Bensaou olyan változókat keresett, amelyek a különböző vállalatoknál együtt mozognak, és szignifikáns kapcsolatot mutatnak olyan tényezőkkel, amelyek általában a stratégiai partnerkapcsolatok jellemzői (pl. bizalom, kölcsönös függőség stb.). Ilyen változónak bizonyult a kapcsolatspecifikus beruházások szintje. Az utóbbi alatt olyan tőkebefektetéseket ért, amelyek nehezen, drágán ültethetők át más kapcsolatokba vagy más szállítóhoz, vevőhöz való átvitel során vesztének értékükből. A modellben a két dimenzió, melyek alapján a különböző vevő-szállító kapcsolatokat elkülöníthetjük, a vevő specifikus beruházásai és a szállító specifikus beruházásai. Az így kialakított négy kapcsolattípus: a piaci csere, fogoly vevő, fogoly szállító és a stratégiai partnerség, amit a 2. ábra szemléltet.

2. ábra

A vevő-szállító partnerkapcsolatok típusai

\begin{tabular}{|c|c|c|c|}
\hline \multirow{4}{*}{ 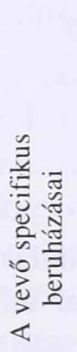 } & \multirow{4}{*}{ 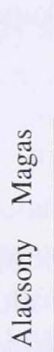 } & \multicolumn{2}{|c|}{ A szállító specifikus beruházásai } \\
\hline & & Alacsony & Magas \\
\hline & & Fogoly vevố & Stratégiai partnerség \\
\hline & & Piaci csere & Fogoly szállító \\
\hline
\end{tabular}

Forrás: Bensaou, M. 1999: 36. o.

Miután megállapítottuk, hogy az adott környezet milyen kapcsolattípust kíván meg, második lépésként hozzá kell rendelni a megfelelő menedzsment megközelítést. Bensaou az egyes kapcsolatmenedzsmenttípusokat három dimenzió szerint osztályozza: (a) információáramlás módja, (b) a vállalat határait kiterjesztő tevékenységek jellemzői, amit nevezzünk a kapcsolattartó feladatok formalizáltságának, (c) a kapcsolaton belüli szociális légkör, a vállalati folyamatok és kultúra. A különböző kapcsolati típusokhoz tartozó működtetési jellemzőket az 1. táblázatban mutatjuk be.

A vállalat helyes kapcsolati portfóliójának felépítése vagy újraépítése az előzőekben ismertetett két kérdéskör összehangolásának eredménye. Tehát három lépésből áll: (1) a kapcsolati típusok stratégiai alapú kiválasztása a termék, a technológia és a piac adta feltételrendszerben, (2) minden típushoz a megfelelő vezetési mód meghatározása, (3) majd e kettő összekapcsolása az elvárt és a tényleges kapcsolati képes- 
Mủködtetési jellemzők a különböző kapcsolati típusoknál

\begin{tabular}{|c|c|}
\hline FOGOLY VEVÖ & STRATÉGIAI PARTNERSÉG \\
\hline $\begin{array}{l}\text { Információáramlás } \\
\text { - Széles körű, részletes, folyamatos és kölcsönös } \\
\text { információcsere } \\
\text { - Rendszeres, gyakori és kölcsönös látogatások } \\
\text { Feladatok formalizáltsága } \\
\text { - Strukturált, elôre jelezhető feladatok } \\
\text { - Sok idốt töltenek a beszállítókkal } \\
\text { Vállalati folyamatok és kultúra } \\
\text { - Feszült légkör, kölcsönös bizalom hiánya } \\
\text { - A szállítókat kezdetben nem vonják be a tervezésbe } \\
\text { - A vevố kooperáció felé hajlik } \\
\text { - A szállítók hírneve nem feltétlenül pozitív }\end{array}$ & $\begin{array}{l}\text { Információáramlás } \\
\text { - Széles köruß, gyakori, részletes információcsere } \\
\text { - Rendszeres kölcsönös látogatások és gyakorlatok } \\
\text { Feladatok formalizáltsága } \\
\text { - Rosszul definiált, rosszul strukturált feladatok } \\
\text { - Nem rutinszerű, gyakori nem várt események } \\
\text { - Sok időt töltenek a szállítókkal koordináció végett } \\
\text { Vállalati folyamatok és kultúra } \\
\text { - Kölcsönös bizalom és elkötelezettség } \\
\text { - A vevő erôs elkötelezettsége } \\
\text { - A szállítók korai bevonása a tervezésbe } \\
\text { - Széles körű kapcsolódó akció és kooperáció } \\
\text { - Jó hírű szállítók }\end{array}$ \\
\hline PIACI CSERE & FOGOLY SZÁLLÍTÓ \\
\hline $\begin{array}{l}\text { Információáramlás } \\
\text { - Korlátozott információcsere, fôként a szerződéskötésnél } \\
\text { - Mû́ködési folyamatok koordinációja és ellenórzése }\end{array}$ & $\begin{array}{l}\text { Információáramlás } \\
\text { - Alacsony szintű információcsere } \\
\text { - Kevés kölcsönös látogatás, főként a szállítók részéről }\end{array}$ \\
\hline $\begin{array}{l}\text { Feladatok formalizáltsága } \\
\text { - Kevés idő eltöltése a szállítóval } \\
\text { - Strukturált, rutin feladatok, kevés függetlenséggel }\end{array}$ & $\begin{array}{l}\text { Feladatok formalizáltsága } \\
\text { - Kevés idő a szállítóval } \\
\text { - Komplex, koordinációs feladatok }\end{array}$ \\
\hline $\begin{array}{l}\text { Vállalati folyamatok és kultúra } \\
\text { - Pozitív szociális légkör } \\
\text { - Közös akciók, kooperáció hiánya } \\
\text { - A szállítókat kezdetben nem vonják be a tervezésbe } \\
\text { - Szállítók jó hírneve és igazolt szakmai tapasztalata }\end{array}$ & $\begin{array}{l}\text { Vállalati folyamatok és kultúra } \\
\text { - Nagyfokú bizalom } \\
\text { - Korlátozott kooperáció } \\
\text { - Kevés közös akció } \\
\text { - A gondok oroszlánrésze a szállítóé }\end{array}$ \\
\hline
\end{tabular}

Forrás: Bensaou, M. 1999: 39. o.

ségek alapján. A harmadik lépés eredményeként kialakul, értékelhetővé válik, hogy a vállalat az egyes üzleti kapcsolatait megfelelően működteti-e. Kutatásunkban meg kívánjuk vizsgálni az üzleti kapcsolatok értékelésének gyakorlati módszereit, az alkalmazott technikákat, mint a stratégiai menedzsment visszacsatolási folyamatának részé6.

\section{Vállalatok egy adott csoportjának üzleti kapcsolatrendszere}

A vállalatok egy adott csoportján itt a Porter-féle iparág fogalmat (azon vállalatok csoportja, amelyek egymással közeli helyettesítési viszonyban lévő termékeket állítanak elő, [Porter, 1980]) tekintjük irányadónak, valamint a hálózatszemléletet. Az értékteremtés különböző szintjeinek értelmezésekor Stabell és Fjeldstad (1998) ötletére építünk, mely szerint az értéklánc modellje számos szolgáltató iparág esetében nem ragadja meg kellőképpen az értékteremtés folya- matát. Stabell és Fjeldstad írásukban technológiai megkülönböztetés alapján további két modellt is javasolnak a probléma áthidalására: az értékteremtő műhelyt (value shop) és az értékteremtő hálózatot (value network). Az értéklánc - ennek megfelelően csak egyike a lehetséges értékteremtő konfigurációknak, nevezetesen az, amelyik ún. „sorba kapcsolt” technológiát használ. Jellegzetes példái a termelő vállalatok. Az értékteremtő műhely intenzív technológiára épít, és egy-egy adott vevői probléma megoldásával teremt értéket. Erre példa lehet az üzleti tanácsadás, az oktatás és az egészségügyi intézmények működése. Az értékteremtő hálózat elsődleges technológiája közvetítő jellegű, az értékteremtés, pedig az egyes ügyfelek közötti kapcsolat megteremtéséből adódik. A szerzők itt a telefontársaságot, közlekedési vállalatot, biztosítót és bankot hozzák példának. Az értékteremtő vállalatcsoportok jellemzését mutatja be a 2. táblázat.

A fenti értékteremtési logikák akár egyes vállalatokon belül is keveredhetnek (pl. a $\mathrm{K}+\mathrm{F}$ mühely jelle- 
Az értékteremtő vállalatcsoportok jellemzői

\begin{tabular}{|c|c|c|c|}
\hline & Értékláncok - Ellátási lánc & Értékteremtő műhely & Értékteremtő hálózat \\
\hline Az értékteremtés logikája & Inputokból outputok előállítása & $\begin{array}{l}\text { Az ügyfelek egyéni és egyedi } \\
\text { problémáinak megoldása }\end{array}$ & $\begin{array}{l}\text { Az ügyfelek közvetlen vagy } \\
\text { közvetett összekapcsolása }\end{array}$ \\
\hline Elsődleges technológia & Sorba kapcsolt & Intenzív & Közvetító \\
\hline $\begin{array}{l}\text { Elsődleges } \\
\text { tevékenységkategóriák }\end{array}$ & $\begin{array}{l}\text { - Bemenô logisztika } \\
\text { - Termelés } \\
\text { - Kimenô logisztika } \\
\text { - Marketing } \\
\text { - Értékesítés utáni szolgálta- } \\
\text { tások }\end{array}$ & $\begin{array}{l}\text { - Problémakeresés és akvizíció } \\
\text { - Problémamegoldás } \\
\text { - Döntés } \\
\text { - Végrehajtás } \\
\text { - Kontroll / értékelés }\end{array}$ & $\begin{array}{l}\text { - A hálózat promóciója és szer- } \\
\text { ződés-menedzsment } \\
\text { - Szolgáltatásnyújtás } \\
\text { - Az infrastruktúra működtetése }\end{array}$ \\
\hline $\begin{array}{l}\text { Másodlagos (támogató) } \\
\text { tevékenységkategóriák }\end{array}$ & $\begin{array}{l}\text { - Vállalati infrastruktúra } \\
\text { - Emberi erőforrás } \\
\text { menedzsment } \\
\text { - Technológia-menedzsment } \\
\text { - Beszerzés }\end{array}$ & $\begin{array}{l}\text { - Vállalati infrastruktúra } \\
\text { - Emberi erőforrás menedzs- } \\
\text { ment } \\
\text { - Technológia-menedzsment } \\
\text { - Beszerzés }\end{array}$ & $\begin{array}{l}\text { - Vállalati infrastruktúra } \\
\text { - Emberi erőforrás } \\
\text { menedzsment } \\
\text { - Technológia-menedzsment } \\
\text { - Hálózatfejlesztés } \\
\text { - Szolgáltatásfejlesztés } \\
\text { - Beszerzés }\end{array}$ \\
\hline $\begin{array}{l}\text { A tevékenységek közötti } \\
\text { kapcsolatok fó logikája }\end{array}$ & Szekvenciális & Ciklikus, spirális & Szimultán, párhuzamos \\
\hline $\begin{array}{l}\text { Az elsődleges tevékenységek } \\
\text { összefüggése }\end{array}$ & $\begin{array}{l}\text { - Közös alap } \\
\text { - Szekvenciális }\end{array}$ & $\begin{array}{l}\text { - Közös alap } \\
\text { - Szekvenciális } \\
\text { - Kölcsönösség }\end{array}$ & $\begin{array}{l}\text { - Közös alap } \\
\text { - Kölcsönösség }\end{array}$ \\
\hline Az értékteremtés logikája & $\begin{array}{l}\text { - A termék értéke a vevők dön- } \\
\text { tési kritériumainak függvénye } \\
\text { - A vevői érték változása } \\
\text { költségcsökkenésből vagy } \\
\text { teljesítményjavulásból adódik, } \\
\text { így a két alapvetổ verseny- } \\
\text { stratégia a költségcsökkentés, } \\
\text { illetve a megkülönböztetés }\end{array}$ & $\begin{array}{l}\text { - Információs aszimmetria } \\
\text { - Egyedi esetek, egyedi prob- } \\
\text { lémák } \\
\text { - Jelentős függőség az egyes } \\
\text { tevékenységek között } \\
\text { - Multidiszciplinaritás } \\
\text { - Információgyűjtés } \\
\text { - Az elsődleges és támogató } \\
\text { tevékenységek egymástól való } \\
\text { függősége erős }\end{array}$ & $\begin{array}{l}\text { - Közvetítők mint klub- } \\
\text { menedzserek } \\
\text { - A szolgáltatás értéke a pozitív } \\
\text { hálózati externáliák mértéké- } \\
\text { tôll függ } \\
\text { - Értéket teremt a szolgáltatás, } \\
\text { a szolgáltatási kapacitás és a } \\
\text { szolgáltatás igénybevételének } \\
\text { lehetősége is } \\
\text { - A közvetítői tevékenység több } \\
\text { szinten párhuzamosan zajlik } \\
\text { - Standardizáció } \\
\text { - Bevezetési szakasz } \\
\text { különbözik }\end{array}$ \\
\hline $\begin{array}{l}\text { Kulcsfontosságú } \\
\text { költségokozók }\end{array}$ & $\begin{array}{l}\text { - Méretgazdaságosság } \\
\text { - Kapacitáskihasználtság }\end{array}$ & & $\begin{array}{l}\text { - Méretgazdaságosság } \\
\text { - Kapacitáskihasználtság }\end{array}$ \\
\hline $\begin{array}{l}\text { Kulcsfontosságú értékteremtő } \\
\text { tényezők }\end{array}$ & & - Reputáció és kapcsolatok & $\begin{array}{l}\text { - Méretgazdaságosság } \\
\text { - Kapacitáskihasználtság }\end{array}$ \\
\hline Az értékrendszer struktúrája & Kapcsolódó láncok & A kiválasztott műhelyek & $\begin{array}{l}\text { Többszintű és összekapcsolódó } \\
\text { hálózatok }\end{array}$ \\
\hline
\end{tabular}

Forrás: Stabell és Fjeldstad (1998) alapján

gû tevékenység, míg a gyártás értéklánc jellegű). A különféle logikák vegyítése versenyelőny forrást jelenthet a vállalatok számára. Mindhárom szinten fontosnak tartjuk a külső kontextuális tényezőket, melyek jelentős befolyással bírhatnak nem csak egy adott vállalat, hanem egy teljes iparág üzleti kapcsolataira. A hálózat szemlélet integrálásával célunk ezeknek a hatásoknak a feltérképezése.

\section{Összefoglalás}

Az előzőekben ismertettük azokat a stratégiához kapcsolódó elméleti megközelítéseket, melyekre „Az üzleti kapcsolatok értékteremtő szerepe" című kutatás során támaszkodunk. Ezek közül kiemeljük, hogy a stratégiai menedzsment és a vállalati gyakorlatban az üzleti kapcsolatok kezelése közötti összekötő kapocs 
mindenkor a stratégiai céloknak való megfeleltetés a legfontosabb tényező. Korábbi kutatási tapasztalataink is megerősítik azt, hogy egyrészt az üzleti partnereknek ismerniük kell már az üzleti kapcsolat kialakítása során azt a stratégiai célt, melynek megvalósítása érdekében az adott kapcsolatot megkötik. A kapcsolat működtetése és értékelése során célszerű a stratégiai cél megvalósulását folyamatosan nyomon követni, majd az eredmények alapján a szükséges változtatásokat megtenni. Másrészt a vállalati stratégia kialakítása során az üzleti partnerek (itt elsősorban vevő és szállítói kapcsolatokra gondolunk) fontos meghatározó tényezőként szerepelnek, hiszen a vállalati értékteremtést alkupozíciójuk nagyban befolyásolja (Porter, 1993). A vevőkkel és szállítókkal kapcsolatos stratégiát gyakran meglehetősen szűklátókörűen határozzák meg, az operatív problémákra helyezve a hangsúlyt. Viszont a vevőkkel és a szállítókkal kapcsolatos stratégia széles összefüggéseire fordított figyelem révén a vállalat javíthatja versenyhelyzetét, csökkentheti sebezhetőségét a versenytársakkal szemben. Fontos tehát a vevők és a szállítók különböző szempontok szerinti értékelése (pl. alkupozíció, koncentráció, átállási költségek, integrálás fenyegetése, specifikus beruházások stb.), majd ezek alapján különböző vevői és szállítói csoportok elkülönítése. A kutatás stratégia szempontból legfontosabb kérdése, hogy a vállalati gyakorlat mennyire tartja fontosnak az üzleti kapcsolatok kezelése során ezt a stratégiai megfelelést. A magyarországi outsourcing szerződések tapasztalatai azt mutatták, hogy a magyarországi kiszerződések többsége azért volt sikertelen, mert nem volt mögöttük a partnerek megfogalmazott stratégiai célja (Könczöl, 2002).

Az üzleti kapcsolatok értékteremtő szerepét vizsgáló kutatásunkban stratégiai nézőpontból azt vizsgáljuk, hogy a magyar vállalati gyakorlatban hogyan jelennek meg az említett elméleti koncepciók. Az ezekhez kapcsolódó fontosabb kutatási kérdéseik a következők: Milyen célokat, elvárásokat fogalmaznak meg a vállalatok az üzleti kapcsolatokhoz kötődően? Milyen tényezőket társítanak az üzleti kapcsolatok sikeréhez? Mely kapcsolattípusokat tartják legfontosabbnak a vállalati stratégia megvalósításában? Megjelenik-e a kapcsolatok kezelésekor a hálózati szemlélet? Erre példa lehet az, hogy az egyik kapcsolatból származó előnyök átültethetők egy másik kapcsolatba. Tekinthetők-e erőforrásnak az üzleti kapcsolatok, ha igen, milyen jellemzőkkel bíró erőforrásnak? A stratégiai visszacsatolási folyamatban megjelennek-e az üzleti kapcsolatok, azaz a vállalati gyakorlatban mérik-e az üzleti kapcsolatok eredményeit vagy sem? Feltételezéseink szerint az eltérő tulajdonosi struktúrával rendelkező, a különböző iparági pozícióban lévő, illetve az eltérő vállalati stratégiát követő vállalatok kapcsolatkezelési gyakorlata között fellelhetők eltérések. A 2004-es „Versenyben a világgal" című kutatási program első eredményei megerősítésül szolgálnak kutatásunkhoz, mivel azt mutatják, hogy a válaszadók 55 százaléka szerint üzleti sikere jelentősen, illetve nagyon jelentős mértékben függ az ellátási láncban együttműködő partnerektől (Chikán - Czakó - Zoltayné, 2004).

\section{Felhasznált irodalom}

Bayer J. - Czakó E. (1999): A stratégiai vezetés sajátosságai a globalizáció közepette, Vezetéstudomány, (30)2, pp. 14-24.

Bensaou, M. (1997): Not by Strategic Partnership Alone: Managing a Portfolios of Relationships, Working Paper, Fontainebleau, INSEAD, 97/110/TM

Bensaou, M. (1999): Portfolios of Buyer-Supplier Relationships, Sloan Management Review, Summer, pp. 35-44.

Bowman, E. H. (1990): Strategy Changes: Possible Worlds and Actual Minds. In: Frederickson, J. W. (ed.): Perspectives on Strategic Management, New York

Camagni, R. (1991): Local "milieu", uncertainty and innovation networks: toward a new dynamic theory of economic space. In: Camagni (ed.): Innovation Networks: Spatial Perspectives. London, Belhaven Press, pp. 121-145.

Chikán A. (2003): Vállalatgazdaságtan, Budapest, Aula

Chikán A. - Czakó E. - Zoltayné Paprika Z. (2004): Fókuszban a verseny, Gyorsjelentés a 2004. évi kérdőíves felmérés eredményeiről, BCE, Vállalatgazdaságtan tanszék, Bp., szeptember

Dyer, J. H. (1996): Specialized supplier networks as a source of competitive advantage: Evidence from the auto industry, Strategic Management Journal, 17(4), pp. 271-291

Elfring, T. - Holberda H. W. (1996): School of Thought in Strategic Management: Fragmentation, Integration or Synthesis?. In: Elfring, T. - Jensen, H. S. - Money, A. (eds.): Theory-Building in the Business Sciences, Papers from the Second EDAMBAS Summer School, Copenhagen, Handelshojskolens Forlag, Distribution: Munksgaard International publishers Ltd., pp. 11-47.

Fama E. - Jensen, M. C. (1983): Separation of ownership and control, Journal of Law an Economics, 26, pp. 301-325.

Gelei A. (2002): Az ellátási lánc menedzsmentkérdései, BKÁE Vállalatgazdaságtan tanszék, 27.sz. Mủhelytanulmány, Budapest, október

Granovetter, $M$. (1985): Economic action an social structure: a theory of embeddedness, American Journal of Sociology, 91, pp. $481-510$

Grant, R. M. (1996): Toward a knowledge-based theory of the firm, Strategic Management Journal 17(Winter Special Issue, pp. $109-122$

Gulati, R. (1995): Social structure and alliance formation pattern: A longitudinal analysis, Administrative Science Quarterly, 40, pp. 619-642

Hamel, G. Y. - Doz, L. - Prahalad, C. K. (1989): Collaborate with your competitor - and win, Harvard Busines Review, 64(1), pp. 133-139

Juhász P. (2005): Az üzleti kapcsolatok pénzügyi értékelése. Vezetéstudomány, 5. sz. pp. 33-41. 
Könczöl E. (2002): Magyar vállalati stratégiák a gyakorlatban, BKÁE, Vállalatgazdaságtan tanszék, Stratégiai menedzsment előadás, 2002. március 14.

Mandják T. (2002): Az üzleti kapcsolatok értéke, BKÁE Gazdálkodástani Ph.D program, Doktori $(\mathrm{PhD})$ értekezés

Mintzberg, H. (1990): Strategy Formation: School of Thought. In: Frederickson, J.W. (ed.): Perspectives on Strategic Management, New York, pp. 107-108

Mohr, J. - Spekman, R. (1994): Characteristics of Partnership Success: Partnership Attributes, Communication Behavior, And Conflict Resolution Techniques, Strategic Management Journal, Vol. 15, pp. 135-152.

Pecze K. (2002): A vállalati hálók stratégiaelméleti megközelítései, Társadalom és Gazdaság 24(2002)2, 287-326

Pfeffer, J. - Salancik, G. (1978): The external control of organisation: a resource dependence perspective, New York, Harper \& Row.

Prahalad C. K. - Hamel G. (1990): The Core Competence of the Corporation. Harvard Business Review, No. 90311, pp: 79-91, magyarul megjelent: Prahalad, C. K. - Hamel, G. (1993): A vállalat alapvető képessége, Vezetéstudomány, 1-2. sz., 34-47

Porter, M. E. (1993): Versenystratégia, Iparágak és versenytársak elemzési módszerei, Budapest, Akadémia Kiadó

Rappaport, A. (2002): A tulajdonosi érték,Útmutató vállalatvezetőknek és befektetőknek, Budapest, Alinea Kiadó

Stabell C. B. - Fjeldstad $\emptyset$. D. (1998): Configuring Value for Competitive Advantage: On Chains, Shops, and Networks. Strategic Management Journal, Vol. 19., 413-437

Whitley, $R$. (1984): The Fragmented State of Management Studies: Reasons and Consequences. Journal of Management Studies 21.
Williamson, O. (1975): Markets and Hierarchies, Ananlysisi and Antitrust Implications, New York, Free Press

Wimmer Á. -Mandják T. (2003): Az üzleti kapcsolatok, mint értékteremtő tényezők?, BKÁE Vállalatgazdaságtan tanszék, 45. sz. Mühelytanulmány, Budapest, december

Wimmer Á. (2004): Teljesítménymérés: az üzleti kapcsolatok értékelése, fejlesztése, menedzsmentje,

BKÁE Vállalatgazdaságtan tanszék, 50. sz. Műhelytanulmány, Budapest, május

Wimmer, Á. (2005): Az üzleti kapcsolatok értékelése, Vezetéstudomány, 5. sz. pp. 4-13.

\section{Lábjegyzetek}

1 A cikk az Üzleti kapcsolatok értékteremtő szerepe c. OTKA F037789 sz. kutatás keretében készuilt. A 2003 decemberében a BKÁE (azóta Budapesti Corvinus Egyetem) Vállalatgazdaságtan tanszéke által szervezett „Üzleti kapcsolatok és értékteremtés” konferencián elhangzott „Egy új fókusz a stratégiai vezetésben: az üzleti kapcsolatok szerepe" címû előadás anyagának kibővített változata.

2 Erről részletesebben lásd Gelei (2002), Wimmer - Mandják (2003).

${ }^{3}$ Errôl részletesen lásd Mandják (2002).

${ }^{4}$ Errôl részletesebben lásd Juhász (2005).

5-5 Erről részletesebben lásd: Pecze (2002).

${ }^{6}$ Erről részletesebben lásd Wimmer (2004, 2005). 